\title{
Profilaktyka syndromu wypalenia zawodowego nauczyciela
}

Prevention of burnout syndrome

\author{
Patrycja Huget \\ Uniwersytet Jagielloński
}

\begin{abstract}
The article presents the modern concept of the process of burnout and the factors determining its formation. The teaching profession, because of the need to build social interaction, requires many skills, called personal resources. Their absence may be a predictor of burnout. Important personal resources are: internal locus of control, creative thinking, building personal relationships, giving social support and hardness. Prevention of burnout syndrome means developing these skills, enabling to cope with difficult situations more effectively.
\end{abstract}

Key words: education, burnout syndrom, occupational burnout prevention

Streszczenie: Artykuł przedstawia współczesną koncepcję procesu wypalenia zawodowego oraz czynniki determinujące jego powstawanie. Zawód nauczyciela ze względu na konieczność budowania interakcji społecznych wymaga wielu umiejętności, nazywanych zasobami osobistymi. Ich brak może być predyktorem wypalenia zawodowego. Ważnymi zasobami osobistymi są: wewnętrzne poczucie kontroli, umiejętność twórczego myślenia, budowanie relacji osobistych, dających wsparcie społeczne oraz twardość. Profilaktyka syndromu wypalenia zawodowego polega na rozwijaniu tych umiejętności, pozwalających efektywnie radzić sobie w trudnych sytuacjach.

Słowa kluczowe: edukacja, syndrom wypalenia zawodowego, profilaktyka wypalenia zawodowego

Poczucie kompetencji społecznych jest jednym z czynników kształtujących indywidualny obraz podjętej przez jednostkę roli zawodowej. Termin kompetencje społeczne jest najczęściej definiowany jako nabyte umiejętności, pozwalające efektywnie funkcjonować w konkretnych sytuacjach społecznych, w których jednostka musi podjąć określone działanie lub rozwiązać jakiś problem. Kompetencje społeczne określają obszar nabytych umiejętności, które umożliwiają odbiór i zrozumienie informacji o ludziach i relacjach, łączących jednostkę $\mathrm{z}$ innymi. W zawodzie nauczyciela pełnią one funkcję szczególną, ponieważ społeczna rola pedagoga wymaga 
umiejętności budowania różnorodnych relacji z innymi ludźmi. Proces edukacji i wychowania przebiega zawsze w pewnej relacji nauczyciel - uczeń, która może być źródłem satysfakcji ale może przysparzać wielu problemów.

\section{Syndrom wypalenia zawodowego}

Efekty działań nauczyciela, będącego równocześnie wychowawcą, zależą od jego umiejętności nawiązywania i utrzymywania kontaktu z uczniem, okazywania mu zrozumienia, dawania poczucia wsparcia. Współczesne publikacje poświęcone zjawisku syndromu wypalenia zawodowego, definiowanemu jako szczególna reakcja organizmu na długotrwały stres, pokazują negatywny wpływ tego zaburzenia na efekty pracy nauczyciela.

Syndrom wypalenia zawodowego (ang. burn - out), badany w naukach społecznych od lat 70. XX w., oznacza zespół objawów, z których najważniejszym jest spadek zaangażowania w pracę zawodową. W 1974 r. amerykański psychiatra Herbert Freudenberger po raz pierwszy użył tego terminu w celu określenia stanu wyczerpania jednostki, spowodowanego nadmiernymi zadaniami stawianymi jej przez środowisko pracy. Objawami zespołu wypalenia zawodowego są zarówno czynniki fizyczne, jak i psychiczne. Powstało kilka koncepcji tego zaburzenia, na przykład Carry’ego Chernissa, Jerry'ego Edelwicha i Archi'ego Brodsky'ego czy Tadeusza Marka. Najbardziej popularną propozycję tego syndromu w naukach społecznych stworzyła Christina Maslach (Maslach 1999), która definiuje syndrom wypalenia zawodowego jako zespół różnorodnych zmian, występujący u osób tworzących w pracy zawodowej intensywne relacje interpersonalne $\mathrm{z}$ innymi ludźmi. Wielowymiarowy model autorki zakłada, że składają się na niego trzy grupy symptomów, będące równocześnie jego etapami.

1. Wyczerpanie emocjonalne i psychofizyczne - jednostka odczuwa nadmierne zmęczenie i poczucie wyczerpania emocjonalnych zasobów, powstające $\mathrm{w}$ efekcie funkcjonowania w zbyt dużej liczbie obciążających relacji interpersonalnych. Na tym etapie jednostka odczuwa zniechęcenie, stałe napięcie psychofizyczne, drażliwość, zmiany somatyczne, takie jak bóle głowy, bezsenność, zaburzenia gastryczne.

2. Depersonalizacja - pojawia się, kiedy jednostka staje się obojętna wobec problemów innych ludzi i zaczyna traktować ich w sposób przedmiotowy. Depersonalizacja może wyrażać się w postawie obojętności lub przez obawę przed kontaktami zawodowymi. Efektem depersonalizacji jest skracanie czasu kontaktu z innymi osobami, powierzchowność relacji i ich uprzedmiotowienie.

3. Obniżenie poczucia dokonań osobistych, obniżenie zadowolenia z osiągnięć zawodowych - oznacza zmniejszenie się zaangażowania $\mathrm{w}$ wykonywaną pracę. Podstawowym przejawem tej fazy syndromu 
wypalenia zawodowego jest spadek satysfakcji z wybranej roli zawodowej, spadek poczucia kompetencji oraz negatywna ocena własnej pracy i jej efektów. Maslach nazywa ten etap erozją zaangażowania w pracę zawodową.

Źródeł wywołujących syndrom wypalenia zawodowego należy szukać zarówno w długim stażu pracy, w cechach osobowościowych pracownika, jak również w czynnikach tkwiących w płaszczyźnie organizacyjnej środowiska pracy, które stawia jednostce coraz większe wymagania w sferze psychologicznej i ekonomicznej. Maslach zwraca uwagę, że środowisko pracy, w którym pracownik jest pomijany w przekazywaniu ważnych informacji, nie ma możliwości wyrażania opinii w sprawach istotnych dla organizacji i jest niedostatecznie nagradzany, sprzyja powstawaniu syndromu wypalenia zawodowego (Maslach 1999, 16-24). W płaszczyźnie indywidualnej jednostka staje się bezradna i ma trudności z podejmowaniem decyzji, spadkowi empatii towarzyszy wzrost zachowań agresywnych w stosunku do innych ludzi, co prowadzi do spadku efektywności pracy.

Inny badacz wypalenia zawodowego Cary Cherniss (Tucholska 2003, 37-41) zwrócił uwagę na zjawisko szoku zawodowego, związanego z krótkim stażem pracy. Ten stan jest konsekwencją poczucia niskiej skuteczności jednostki wchodzącej w rolę zawodową. Autor poszukuje źródeł wypalenia w zawodach społecznych, odnoszących się przede wszystkim do ludzi młodych, wskazując na brak pewności posiadania wystarczających kompetencji do efektywnego pełnienia roli zawodowej, negatywne cechy i zachowania podopiecznych, nadmiar obowiązków związanych z biurokracją, brak stymulacji do osobistego rozwoju oraz wspólnotowości. Cherniss wyróżnił cztery podejścia do kariery zawodowej młodych ludzi rozpoczynających karierę zawodową, równocześnie wskazując na zależność pomiędzy stosunkiem do pracy a możliwością wystąpienia syndromu wypalenia zawodowego.

1. Działacz społeczny - ma potrzebę niesienia pomocy w większym stopniu niż jest to wymagane. Dąży do wprowadzenia zmian społecznych, jest nastawiony do pracy nowatorsko.

2. Rzemieślnik - posiada wewnętrzną motywację do pracy. Jest zasadniczy i konkretny w podejściu do zadań.

3. Karierowicz - wyróżnia go dążenie do sukcesu, który definiuje w kategoriach prestiżu, szacunku, uznania i korzyści materialnych.

4. Pracownik inwestujący w siebie - koncentruje się głównie na życiu osobistym i jego jakości, w mniejszym stopniu na pracy zawodowej.

Syndromem wypalenia zawodowego, zdaniem Chernissa, zagrożeni są przede wszystkim działacze społeczni i rzemieślnicy. Ich cele i plany zawodowe są często ambitne i trudne do realizacji, co w efekcie może prowadzić do sytuacji, w której pracownik zaczyna postrzegać miejsce pracy jako źródło stresu. 
Cherniss był pierwszym badaczem wypalenia zawodowego, który zwrócił uwagę na znaczenie działań profilaktycznych $\mathrm{w}$ tym procesie, podkreślając związek pomiędzy odczuwaniem wypalenia a stylem radzenia sobie ze stresem. Szczególnie niekorzystne są strategie unikania i wycofywania. Syndrom wypalenia zawodowego, według tego autora, powstaje na skutek działania długotrwałego stresu i działania profilaktyczne powinny być skoncentrowane na rozwijaniu umiejętności radzenia sobie w sytuacjach trudnych.

\section{Współczesna koncepcja działań profilaktycznych}

W naukach humanistycznych profilaktyka definiowana jest jako proces wspierający jednostkę $\mathrm{w}$ prawidłowym rozwoju i zdrowym życiu. Profilaktyka - jak podaje Krzysztof Zajączkowski - to proces polegający na wspieraniu zdrowia przez umożliwienie ludziom uzyskania pomocy potrzebnej do przeciwstawienia się trudnościom życiowym oraz osiągania subiektywnie satysfakcjonującego, społecznie konstruktywnego i bogatego życia (Zajączkowski 1997).

W poglądach na temat profilaktyki w ostatnich trzech dekadach można dostrzec wyraźną zmianę. Początkowo podstawą wszelkich działań było eliminowanie czynników ryzyka, czyli cech sytuacji i warunków sprzyjających powstawaniu zachowań ryzykownych, do których zalicza się przede wszystkim uzależnienia, zachowania agresywne, wczesną aktywność seksualną. W tradycyjnym modelu działań profilaktycznych (Świątkiewicz 2002) celem wszelkich działań było głównie zwalczanie patologii przez uświadamianie wpływu czynników ryzyka na rozwój jednostki. Profilaktyka w takim rozumieniu była działalnością defensywną, skoncentrowaną na czynnikach ryzyka i nastawioną na przekaz „nie rób tego”.

W modelu współczesnym, nazywanym profilaktyką pozytywną, celem wszystkich działań jest wzmacnianie czynników chroniących, czyli cech, sytuacji i warunków zwiększających odporność jednostki na działanie czynników ryzyka. We współczesnej koncepcji panuje przekonanie, że wybór umiejętności promowanych w działaniach profilaktycznych powinien być dokonany na podstawie całościowego i realistycznego rozumienia natury człowieka i jego potrzeb. Całokształt wiedzy antropologicznej potwierdza, że człowiek jest zdolny do racjonalnego myślenia, podejmowania rozważnych decyzji, z drugiej jednak strony jest zagrożony przez środowisko zewnętrzne oraz osobistą słabość i niedojrzałość. Konieczne jest zatem rozwijanie czterech grup umiejętności: zdolności realistycznego myślenia, dojrzałości emocjonalnej, gotowości do budowania odpowiedzialnych więzi międzyludzkich oraz zdolności odkrywania i respektowania podstawowych wartości i norm moralnych (Dziewiecki 2000, 14-16).

Zmiana rozumienia istoty działań profilaktycznych w naukach społecznych dokonała się kilkadziesiąt lat po przedefiniowaniu pojęcia zdrowia. 
Do lat 50. XX w. zdrowie opisywano w sposób obiektywny i jednocześnie negatywny -jako brak zakłóceń w funkcjonowaniu organizmu, czylijako brak choroby. Pojawienie się medycyny psychosomatycznej pozwoliło dostrzec rolę czynników psychosomatycznych w powstawaniu choroby. Czynniki biologiczne odpowiedzialne są tylko za część zachorowań i nie każda jednostka, która zetknęła się z czynnikiem chorobotwórczym, choruje. Jak zauważa Helena Wrona-Polańska (Wrona-Polańska 2003, 22), skrajnie biologiczne podejście do zdrowia jako kategorii negatywnej, będącej zaprzeczeniem choroby, okazało się niewystarczające. Współcześnie w naukach medycznych i humanistycznych formułowane są koncepcje zdrowia, opierające się na idei holizmu, zgodnie z którymi organizm człowieka stanowi integralną całość powiązaną ze środowiskiem, podlegającą zasadom regulacji i samoregulacji.

Współcześnie zdrowie definiuje się jako proces poszukiwania i utrzymywania dynamicznej równowagi pomiędzy możliwościami człowieka a wymaganiami środowiska społecznego. Stan zdrowia wyraża się w relacji wzajemnie na siebie oddziałujących dostępnych człowiekowi zasobów, jego zachowania i wymagań życia codziennego (Sęk 2007). Przedmiotem współczesnych badań są indywidualne i społeczne zasoby, czyli tkwiące w człowieku oraz w jego otoczeniu możliwości i czynniki pozwalające osiągnąć stan zdrowia.

Pojęcie zasobów spotyka się najczęściej w badaniach dotyczących znaczenia czynników ułatwiających radzenie sobie ze stresem. Wyróżnia się zasoby wewnętrzne, nazywane również podmiotowymi oraz zewnętrzne, czyli środowiskowe. Współcześnie przyjmuje się, że złożone układy czynników biologicznych, osobowościowych i poznawczych, wraz z określoną konstelacją czynników natury społecznej i kulturowej, mogą sprzyjać radzeniu sobie w sytuacjach trudnych i przeciwdziałać powstawaniu negatywnych konsekwencji dla jednostki (Gaweł 2014, 29-30). Zasobami określa się najczęściej zdolności i środki sprzyjające radzeniu sobie ze stresującymi warunkami życia.

\section{Przeciwdziałanie wypaleniu zawodowemu nauczyciela}

Rozwój aktywności zawodowej człowieka można przedstawić w formie kontinuum. Na jednym biegunie mieści się zaangażowanie w pracę zawodową, połączone z fascynacją nowymi doświadczeniami, często występujące u pracowników młodych, natomiast na drugim końcu znajdują się wyczerpanie i brak satysfakcji z własnych osiągnięć. Zawód nauczyciela zwiększa ryzyko wystąpienia objawów syndromu wypalenia zawodowego ze względu na konieczność budowania wielu interakcji z uczniami, rodzicami i innymi pracownikami szkoły. Istnieje jednak grupa umiejętności, które można nazwać zasobami osobistymi lub czynnikami chroniącymi. Ich rozwój wpisuje się w nurt działań zaliczanych do współczesnej koncepcji profilaktyki. 
Najważniejszymi zasobami osobistymi obniżającymi zagrożenie wystąpienia objawów syndromu wypalenia zawodowego są: wewnętrzne poczucie kontroli, twardość (resilience, hardiness), twórcze myślenie oraz zdolność budowania relacji z ludźmi dostarczających wsparcia społecznego.

Umiejscowienie poczucia kontroli (locus of control) zostało wprowadzone przez psychologa Juliana B. Rottera i oznacza subiektywne i zgeneralizowane przekonanie jednostki na temat źródła kontroli wzmocnień. Poczucie kontroli jest indywidualną właściwością człowieka, którą można traktować jako wymiar osobowości dający się przedstawić na kontinuum od poczucia kontroli zewnętrznej do poczucia kontroli wewnętrznej (Szmigielska 1999, 21-22). Jednostka uczy się spostrzegać zależność pomiędzy własnym zachowaniem a jego skutkami. Powodzenia lub porażki, które ją spotykają w życiu, interpretuje jako następstwa własnych zachowań lub jako konsekwencję działania czynników zewnętrznych. Jeżeli człowiek spostrzega, że źródłem wzmocnień są jego własne działania lub umiejętności, można mówić o wewnętrznym umiejscowieniu kontroli. Wzmocnienie interpretowane jako skutek działania zbiegu okoliczności lub szczęścia wskazuje na zewnętrzne umiejscowienie poczucia kontroli. Osoby zewnątrzsterowne posiadają przekonanie o braku możliwości wpływania na sytuację stresową. Są w większym stopniu zagrożone syndromem wypalenia zawodowego. Z badań przeprowadzonych przez Marię Kliś i Joannę Kossewską (Kliś, Kossewska 1998) wynika, że istnieje związek pomiędzy satysfakcją z pracy zawodowej a umiejscowieniem poczucia kontroli. Jednostki zadowolone z pracy są jednocześnie bardziej wewnątrzsterowne.

Twardość (hardiness), nazywana również elastycznością, jest indywidualnym zasobem określającym poziom odporności na stres (Tucholska 2003, 71). Jednostki charakteryzujące się wysokim poziomem twardości są mniej podatne na sytuacje stresowe i stosują efektywne strategie radzenia sobie ze stresem $\mathrm{w}$ przeciwieństwie do osób posiadających niski poziom twardości.

Twórczość jest cechą, którą często zalicza się do zasobów indywidualnych, pozwalającą radzić sobie w sytuacjach trudnych. Twórcze radzenie sobie ze stresem pozwala jednostce funkcjonować w sytuacjach ekstremalnych, takich jak na przykład ciężka choroba. Wskaźnikami postawy twórczej w naukach społecznych są cechy myślenia i rozwiązywania problemów oraz określone cechy osobowości. Oceniając poziom myślenia twórczego, badacze, opierając się na koncepcji Joya P. Guilforda, biorą przede wszystkim pod uwagę zdolność myślenia dywergencyjnego, definiowanego jako zdolność do generowania wielu różnych rozwiązań określonego problemu. Za cechy tego rodzaju myślenia przyjmuje się (Szmidt 2008, 41-42):

1. płynność myślenia - zdolność wytwarzania w krótkim czasie wielu słów, sentencji, idei, pomysłów. Wskaźnikiem poziomu płynności myślenia jest liczba wytworzonych w określonym czasie pomysłów. 
2. Giętkość myślenia - zdolność wytwarzania jakościowo różnych pomysłów i zmiany kierunku poszukiwań, umiejętność dostosowania metod rozwiązywania problemów do zmieniających się okoliczności. Giętkość jest przeciwieństwem sztywności myślenia. Autor wyróżnił dwa rodzaje giętkości: spontaniczną, która polega na niewymuszonej zmianie kierunku myślenia, i adaptacyjną, związaną z modyfikacją procesów myślenia pod wpływem konieczności dostosowania się do warunków zadania.

3. Oryginalność myślenia - zdolność wychodzenia poza stereotypowe, najbardziej narzucające się rozwiązania, umożliwiająca dostrzeganie nowych niezwykłych aspektów sytuacji problemowej. Myślenie jest bardziej oryginalne, im lepiej potrafimy znajdować rozwiązania: niezwykłe, nieoczekiwane, niekonwencjonalne.

4. Wrażliwość na problemy - polega na umiejętności dostrzegania problemów, które występują w danej sytuacji.

W psychologii humanistycznej można znaleźć idealny obraz osobowości twórczej, która integruje różnorodne umiejętności poznawcze, uczuciowe i behawioralne. Są to takie umiejętności, jak otwartość umysłu, zdolność dziwienia się, brak obawy przed nieznanym, zdolność koncentracji uwagi, spontaniczność i ekspresyjność, życzliwe poczucie humoru, umiłowanie gier i zabaw.

W latach 60. Morris I. Stein (Popek 2000) dokonał syntezy wyników badań, których celem było określenie zbioru cech, determinujących zdolność tworzenia. Wynikało z niej, że jednostki twórcze posiadają cechy przywódcze, przejawiają inicjatywę, stanowczość, niezależność, konstruktywny krytycyzm, są mniej konwencjonalne i zahamowane, posiadają silną motywację i zapał do pracy. Badacze zwracali uwagę na ich szerokie zainteresowania, dużą wiedzę, estetyczny stosunek do świata i niewielkie zainteresowanie sprawami ekonomicznymi. W sferze emocjonalnej zaznaczały się takie cechy, jak witalność, entuzjazm, brak agresywności, brak zainteresowania sprawami relacji międzyludzkich, niski poziom towarzyskości i introwersja. Zdaniem niektórych badaczy zdolności twórcze korelują ze złym przystosowaniem społecznym i emocjonalnym niezrównoważeniem, które jednak nie wpływają na zdolność radzenia sobie w pracy.

Jednym z wymiarów osobowości, wpływającym bardzo wyraźnie na twórcze zdolności jednostki, jest konformizm - nonkonformizm. Przez termin konformizm rozumie się skłonność do podporządkowania się naciskom grupy, zmianę zachowania lub poglądów pod wpływem obecności innych ludzi. Nonkonformizm jako przeciwny biegun tego samego wymiaru jest rozumiany jako nieodzowna cecha osobowości jednostek twórczych, zaznaczająca się przeciwstawianiem się naciskom społecznym, opiniom, poglądom innych ludzi. Jak zauważa Stanisław Popek, nonkonformizm jest rodzajem aktywności poznawczej, emocjonalnej i behawioralnej, determinującej proces twórczy, pod warunkiem, że przeciwstawianie się łączy 
się z wytwarzaniem i konkretyzowaniem w działaniu własnych pomysłów (Popek 2001).

Marc Runco odrzuca możliwość znalezienia zbioru kilku kluczowych cech osobowości twórczej (Szmidt 2009, 41). Uważa, że to, czego poszukują badacze, można scharakteryzować jako triadę trzech komponentów: świadomej inwestycji czasu, wysiłku i różnorodnych indywidualnych cech, tendencji i charakterystyk. Zalicza do nich: autonomię, elastyczność, preferowanie złożoności, otwartość na doświadczenia, wrażliwość, zamiłowanie do zabawy, tolerowanie dwuznaczności, tolerancję dla ryzyka, motywację wewnętrzną, skuteczność osobistą oraz szerokie zainteresowania i ciekawość.

Kolejnym czynnikiem zaliczanym do zasobów indywidualnych jest umiejętność budowania relacji z innymi ludźmi, dających poczucie wsparcia. Wsparcie społeczne w naukach społecznych jest uważane za termin niejednoznaczny. W ujęciu strukturalnym może być definiowane jako obiektywnie istniejące i dostępne sieci międzyludzkie, które przez istnienie kontaktów społecznych pełnią funkcję pomocną wobec osób znajdujących się w trudnej sytuacji. Częściej charakteryzuje się wsparcie społeczne w ujęciu funkcjonalnym jako rodzaj interakcji społecznej, która zostaje podjęta przez uczestników sytuacji trudnej lub krytycznej (Sęk, Cieślak 2006, 10). Wsparcie daje człowiekowi poczucie przynależności i dodatnio wpływa na jakość życia. Zgodnie z hipotezą buforową doświadczanie wsparcia społecznego podnosi ocenę posiadanych kompetencji, pozwala uzyskać wgląd we własne możliwości, zwiększa poczucie zaradności oraz podnosi samoocenę.

W profilaktyce syndromu wypalenia zawodowego w zawodzie nauczyciela ważna jest każda aktywność, która ma na celu poszerzanie kompetencji zawodowych, pogłębianie wiedzy, rozwijanie zdolności twórczego myślenia oraz kształtowanie umiejętności komunikacji interpersonalnej. Posiadanie tych umiejętności pozwala jednostce efektywniej radzić sobie w sytuacjach trudnych.

\section{Bibliografia:}

Dziewiecki Marek, 2000, Nowoczesna profilaktyka uzależnień, Kielce.

Gaweł Anna, 2014, Zasoby zdrowotne młodziė̇y gimnazjalnej w kontekście ekosystemu szkoły, Kraków.

Kliś Maria, Kossewska Joanna, 1998, Cechy osobowościowe nauczycieli a syndrom wypalenia zawodowego, „Psychologia Wychowawcza”.

Maslach Christina, 1999, Wypalenie się - utrata troski o człowieka, w: Psychologia i życie, Zimbardo P., Ruch F. L. (red.), Warszawa.

Maslach Christina, Leiter Michael, 2011, Prawda o wypaleniu zawodowym. Co zrobić ze stresem $w$ organizacji, Warszawa.

Popek Stanisław, 2000, Kwestionariusz twórczego zachowania KAHN, Lublin. Popek Stanisław, 2001, Człowiek jako jednostka twórcza, Lublin. 
Sęk Helena, Cieślak Roman, 2006, Wsparcie społeczne - sposoby definiowania, rodzaje i źródła wsparcia, wybrane koncepcje teoretyczne, Sęk H., Cieślak R. (red.), Wsparcie społeczne, stres i zdrowie, Warszawa.

Sęk Helena, 2007, Psychologia wobec promocji zdrowia, Heszen-Niejodek I., Sęk H. (red.), Psychologia zdrowia, Warszawa.

Szmidt Krzysztof J., 2009, W kierunku „kreatologii”. Charakterystyka najnowszych syntez wiedzy o twórczości (Weisberg, Runco, Sawyer), w: Popek S. (red.), Psychologia twórczości. Nowe horyzonty, Lublin.

Szmidt Krzysztof J., 2008, Trening kreatywności. Podręcznik dla pedagogów, psychologów i trenerów grupowych, Gliwice.

Szmigielska Barbara, 1999, Społeczno-uczeniowa teoria osobowości Juliana B. Rottera, w: Gałdowa A. (red.), Klasyczne i współczesne teorie osobowości, Kraków.

Świątkiewicz Grażyna, 2002, Profilaktyka w środowisku lokalnym, Warszawa.

Tucholska Stanisława, 2003, Wypalenie zawodowe nauczycieli, Lublin.

Wrona-Polańska Helena, 2003, Zdrowie jako funkcja twórczego radzenia sobie ze stresem. Psychologiczne mechanizmy i uwarunkowania zdrowia $w$ zawodzie nauczyciela, Kraków.

Zajączkowski Krzysztof, 1997, Profilaktyka zachowań dewiacyjnych dzieci i młodzieży, Torun.

\section{O Autorce:}

Patrycja Huget - doktor, psycholog z wieloletnim doświadczeniem praktycznym. Pracownik Katedry Polonistycznej Edukacji Nauczycielskiej Wydziału Polonistyki Uniwersytetu Jagiellońskiego. Zainteresowania badawcze koncentrują się wokół problematyki specyficznych trudności w uczeniu się, profilaktyki zaburzeń w zachowaniu dzieci i młodzieży oraz rozwoju postawy twórczej uczniów. 
